\title{
災害救助支援のための情報共有プラットフォーム
}

\author{
一データ仲介による情報システム連携
}

野田 五十樹

東日本大震災ではさまざまな「想定外」に国や自治体の防災体制が翻弄されることとなった。このような事態を軽減するためには、さま ざまな要請に臨機応変に対応して構成していける災害情報システムが望まれる。この論文ではその基盤として、デー夕仲介による緩い 情報システム連携の考え方とそれに基づく減災情報共有プラットフォームを提案する。このプラットフォームではさまざまな情報システム を簡便に連携させることができ、災害時の多様な状況に対応してシステムを迅速に組み上げることができる。デー夕仲介によるシステム 連携の考え方は東日本大震災でも有効に働いており、今後、この考え方に基づく設計の在り方を普及させていくことが重要である。

キーワード: 情報共有、防災・減災、データベース、情報システム連携

\section{Information sharing platform to assist rescue activities in huge disasters}

- System linkage via data mediation -

Itsuki NoDA

\begin{abstract}
Various "unexpected" situations caused by the Great East Japan Earthquake severely hampered disaster-control systems of Japanese national and local governments. A flexible framework for disaster information systems that is reorganizable depending on circumstances is required to mitigate such serious situations. In this article, I propose the concept of "loose linkages" of information systems based on data mediation and a platform for disaster mitigation information sharing. The platform enables us to link various systems quickly, so that we can reconstruct disaster information systems according to various situations in major disasters. I found that the concept was effective for the Great East Japan Earthquake along with various ad-hoc activities of information volunteers. We should spread this concept and platform to Japanese national and local governments, and support organizations to prepare for future disasters.
\end{abstract}

Keywords : Information sharing, disaster mitigation, database, system integration

\section{1 はじめに}

2011 年 3 月 11 日の東北太平洋沖地震は、自然災害の猛 威とともに、災害の多様さ、予測困難さを我々に思い知ら せることになった。この 15 年あまりの間、我が国の震災対 策の多くは、阪神淡路大震災を一つのモデルとして進めら れてきた。阪神淡路のケースでは直下型地震による家屋倒 壊や火災延焼により多数の被害者が出ることになり、広域 の消防・医療応援とそれを支援するための情報共有が大き な課題となった。これを受け、初動における組織間の事前 取り決めや自治体間の相互応援体制等の整備は徐々に進 められてきた。一方、今回の震災では被害者の大半は大津 波によるものであり、時間差で襲ってくる津波に対する警 報の伝達等に多くの課題を突きつけた。もちろん阪神淡路 の経験が無駄になったわけではなく、関係各機関の初動 や広域連携についても一定の進歩がみられ、長年にわたる 取り組みは災害対応として着実な改善をもたらしている。
ただ、災害対策には十分というレベルはなく、どのように万 全の対策をしても「想定外」を覚悟しなければならないこ とを、今回の震災で再認識することになった。

災害列島と言われる我が国 ${ }^{[1]}$ では、災害に対する備えを 継続的に整えていかなければならない。各自治体は、地震 や火山噴火、津波、台風・風水害、雪害等、多種多様な自 然災害からは逃れることはできない。また、首都圈や京阪 神・中京地区等の大都市圈では、建物や交通機関が密に集 積しており、テロや災害が発生した際に影響が拡大すること が懸念されている。実際、日本の大都市は災害等の危険度

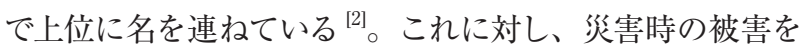
少しでも軽減する対策を打っていくことは、住民の生命・財 産を守ることに加え、安心して投資していける地域としての 地位を確立して産業振興を助ける意味でも重要である。

災害対策では、耐震等ハード面での備えと並んで、情報 収集・活用の面での枠組み・体制作りが必須である。想定

産業技術総合研究所 サービス工学研究センター テ305-8568つくば市梅園 1-1-1 中央第 2

Center for Service Research, AIST Tsukuba Central 2, 1-1-1 Umezono, Tsukuba 305-8568, Japan E-mail: i.noda@aist.go.jp

Original manuscript received December 20, 2011, Revisions received February 22, 2012, Accepted March 1, 2012 
外を含めた災害に対するには臨機応変な判断が不可欠であ り、そのためにはできるだけ多くの、そして確度の高い情

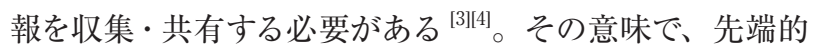
な IT を用いた防災情報システムが災害対策を改善できる 余地は少なからずあると思われる。しかし実際には、東日 本大震災でも相変わらず手書きのメモが壁一面に張られ、 ホワイトボードにさまざまな情報が書き散らされているのが 現実である。また、組織間の連絡も相変わらず FAXが主 流であり、情報伝達の遅延や欠落の原因となっている。も ちろん、この情報収集・共有の重要性は広く認識されてお り、国や各県・市町村において、各種防災情報システムが 構築されているが、残念ながら、今回の震災でもこれらの システムが期待どおりに効果を発揮したという事例はあまり 耳にしない。この防災情報システムがなかなか活用できな い理由としては、防災専用で変更のきかない閉じたシステム として設計されている点が大きいと思われる。他の災害対 策と同様、情報システムについても臨機応変が求められる。

このような困難を克服できる災害情報システムを設計する 上で重要となる視点が、臨機応変さとライフサイクルであ る。災害で生じる現象は多岐にわたるため、それらすべて に対処できる情報処理機能を予見して事前にシステムに組 み込んでおくことはおよそ不可能である。実際、東日本大 震災後の自治体ヒアリング ${ }^{[5]}$ でも、事前の防災計画をいろ いろと手直しせざるを得なかったことが明らかになってい る。一方、今回の震災では 5 節でも述べるように、情報ボ ランティアによる支援が有効に機能した。このボランティア による活動の特徵は事後に必要に応じてシステムを組み上 げていく臨機応変さである。もちろん災害情報システムを すべて事後に構築することは現実的ではないが、このよう な臨機応変さを取り込む余地をシステム設計時に考慮して おくことは、必須の要件と考えられる。また、ライフサイク ルの視点とは、日進月歩の情報技術の進歩と百年・千年 に一度の大災害という、時間スケールの差の捕らえ方であ る。つまり、その時々の最先端技術を数多く盛り达むこと よりも、時間の経過とともに各技術が廃れて次の技術に引 き継がれていくところに留意して、災害情報システムを設計 していかなければならない。

この二つの視点を取り込んだ災害情報システム設計手法 を確立するため、この論文では「データ中心のアドホックな システム構築」という考え方を導入する。この考え方では、 次の 3 点を情報システムの構築時の設計方針とする。

・オープンシステム : システムの各機能を切り出しての利 用や他のシステムとの連携を前提として、情報システムを 構築する設計方針。臨機応変およびライフサイクルの視 点に応える。
・汎用的データフォーマット・プロトコル標準: 機能の連 携を簡単化し、また、システムの置き換え・引き継ぎを容 易にするため、連携部分を共通化する設計方針。臨機応 変およびライフサイクルの視点に応える。

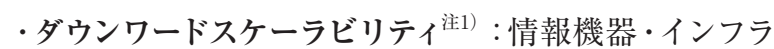
の規模や種類を選ばずにどこでも動作させられるため の設計方針。臨機応変の視点に応える。

そして、これらの設計方針を実現する基盤技術として、 システムの基本デザインとなる減災情報プラットフォームと その核となる共有プロトコル (MISP) およびデータベース

（DaRuMa）を紹介する。これら視点・設計方針・基盤 技術の関係を図 1 に示す。

次節以降、この論文は次のような構成をとる。まず 2 章 において減災情報共有プラットフォームとそのプロトコル． データベースについて述べる。次に 3 章に扔いて、提案プ ラットフォームの設計方針を防災・減災の視点で議論する。 4 章では、提案プラットフォームによる害証システムや実働 システム例について紹介する。さらに 5 章では東日本大震 災でのいくつかの事例を取り上げ、上記の設計方針の有効 性と問題点を議論する。

\section{2 減災情報共有プラットフォームの設計思想と実装}

この章ではまず、この論文で提案する災害情報共有の ための枠組みである減災情報共有プラットフォーム ${ }^{[6] 1] 7]} の$ 設計思想と、その実装の要となる減災情報共有プロトコル

(Mitigation Information Sharing Protocol、以下、MISP) および減災情報共有データベース (DAtabase for Rescue Utility Management、DaRuMa）について述べる。

\section{1 データ中心のモジュール連携による減災情報共有} プラットフォーム

我々が想定している災害情報共有の枠組みは、図 2 に 示すように、異なる組織で運用される各種災害情報システム

（以下ではモジュールと呼ぶ）を、データベースを介して連 携させるものである。この枠組みをここでは減災情報共有 プラットフォームと呼ぶ。

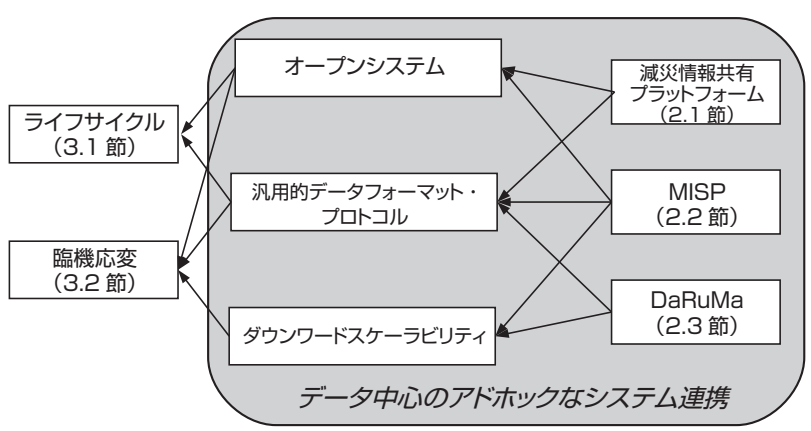

図 1 災害情報システムの視点・設計方針・基盤技術の関係 
前章でも述べているようにこのプラットフォームの重要な 考え方は、デー夕を仲介したアドホックなモジュール連携で ある。すなわち、各モジュールは、他のモジュールの機能 を直接呼び出すのではなく、他モジュールがデータベースに 書き出したデー夕を取得することで、情報の共有や機能の 連携を実現する。データの仲介に限定することで、連携の 形態が整理され、汎用性の高い枠組みを提供できると考え る。このような、中心にハブとなる仲介モジュールをおいて モジュールを連携させる設計方針は、特に目新しいもので はないが、ハブの機能とデー夕の仲介のみに連携の形態を 限定することで、継続的かつ柔軟なシステム改変が可能と なる。近年では Web サービスのマッシュアップという考え 方で、機能を高度に連携させる仕組みも数多く運用されて いるが、この論文で提案する枠組みでは臨機応変およびラ イフサイクルの視点を考慮してあえて単純な仕組みを採用す る。この妥当性については 3 章において議論する。

\section{2 減災情報共有プロトコルMISP}

減災情報共有プラットフォームの要となるのが、共通 プロトコルとなる MISP ${ }^{[8]}$ である。 MISP は XML をべー スとしたデータベースアクセスプロトコルであり、データ ベースで必要とされる基本機能、すなわち、デー夕の検索

(Query)、登録 (Insert)、修正 (Update、Delete) の呼 び出し方を定めている(図 3 の上部)。SQL (Structured Query Language) におけるテーブルジョインといったデー 夕再構成機能はあえて用意せず、基本的な機能に絞り込む ことでデー夕表現の単純化を促し、デー夕仲介のモジュー ル連携を狙っている。さらに、アドホックな連携を助け るための機能として、オンラインでのデータ構造定義機能

(RegisterFeatureType) を含む、データベースのメ夕機 能を提供している (図 3 の下部)。このデータ構造定義機
能では、取り扱うデータの型をXML Schema によってオン ラインでデータベースに追加登録できる。このため、プラッ トフォームの運用中にシステムを停止させずに新規データ型 を追加することが可能であり、新規モジュールの追加時に リアルタイムに新規データ型のテスト・修正ができるように なる。これは数多くの組織にまたがってモジュールを連携 させることが必要となる防災情報システム統合では重要な 機能となる。すなわち、新しいモジュールを追加する際、 必要となる新規デー夕型の登録のためにシステム全体を停 止する等のコストが発生すると、試行錯誤を必要とするモ ジュール連携が進みにくくなる。オンラインのデータ定義機 能の呼び出しをモジュール側に解放することで、これらの 障害を回避し、システム連携を円滑にすることを、この仕 様は狙っている。

このプロトコル設計にあたっては、機能の単純さと記述 の簡潔さを維持することを重視した。通常のインターネット のプロトコル設計では、高機能さや機能の拡張性を担保 することが意識されがちである。例えば XML データベー スの検索プロトコルとしては XPath や XQuery が提案され てきているが、高機能な検索やデー夕再構成を実現するた め、徐々に複雑になりつつある。日進月歩の情報技術の分 野では、このような短期的な拡張性は重要ではあるが、後 で議論するように、災害対処のライフサイクルが 10 年 100 年であることを考慮した場合、拡張性にも高機能追及とは 別の視点が必要であり、この論文で提案するプラットフォー ムでは、単純さ・簡潔さを重視することとした。これについ ては 3 章で議論する。

MISP の基本機能はWFS (Web Feature Service) ${ }^{[9]}$ をベースとしており、WFS と関連する GML (Geography Markup Language) ${ }^{[10]}$ XML Schema ${ }^{[1]}$ 、SOAP (Simple

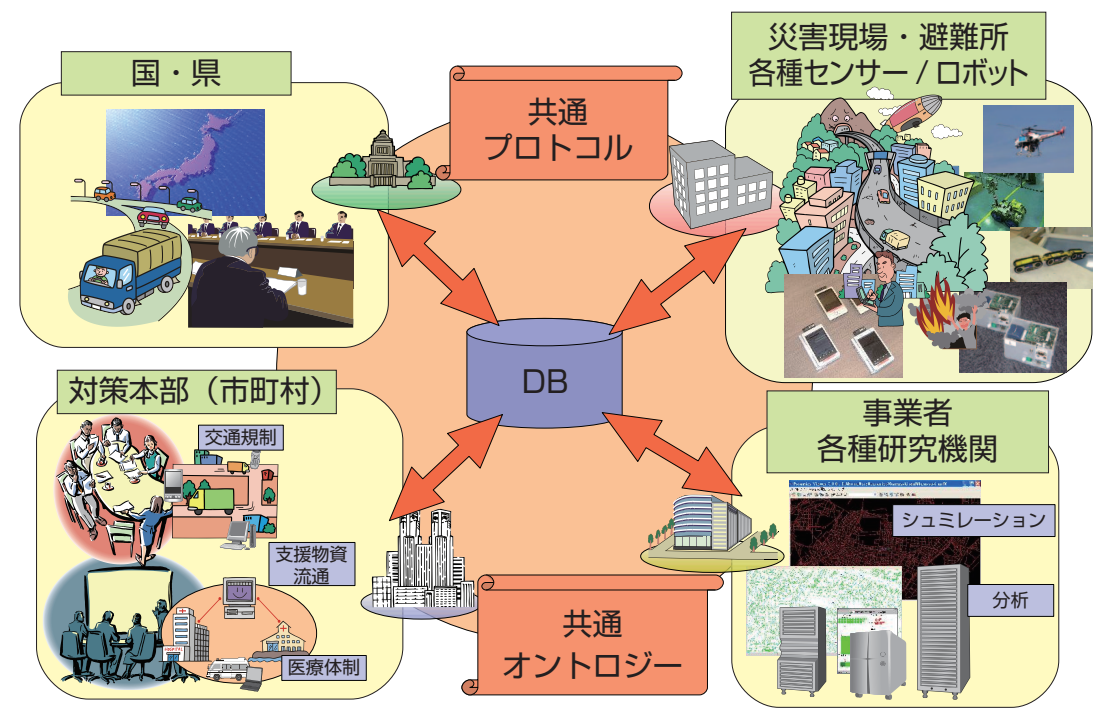

図 2 滅災情報共有プラットフォーム 
Object Access Protocol) ${ }^{[12]}$ 等の各種標準を用い、その上 で災害情報を共有するにあたり、不足すると思われる部分 を追加する形で規定した。

これらはすでに ISO 等で標準化され広く使われている規 格であり、現存のシステムや今後作成されるシステムとの親 和性を高めることを目指している。標準の採用は同時に既 存のツール等をそのまま利用できるという利点があり、災 害以外の目的のためのシステムとの連携や応用が期待でき る。また、センサーシステムのような、大きな計算能力の 期待できないシステムでも扱えるよう簡潔さを保たせ、ダウ ンワードスケーラビリティを担保している

表記形式としての XML の採用の理由は、近年の多くの システムでの採用と同じく、そのデータ表現としての汎用性・ 柔軟性・拡張性にある。基本デー夕型としては数值 (整数· 実数）と文字列に加え、災害情報では不可欠の空間・地 理表現 (GMLで定義されている点・線・面) および時間表 現の 4 つを用意してあり注 2)、それらの任意の組み合わせを XML Schemaで定義することで、多様なデー夕構造を扱 えるようになっている。つまり、データとしては災害情報に 限らず任意の定型デー夕を扱えるようになっており、平時で の業務でも活用できるようになっている。

MISP のプロトコル例を図 4 に示す。この例は RoadLink というタイプの地物を定義しており、その地物データは、 misp:GeometryFeature に定義される要素 (位置形状の情 報要素 gml:GeometryProperty を定義している）に加え、 GML で記述される representativePoint や交差点等のノー ドのリスト (nodeList)、道幅 (roadWidth) 等により構成 されていることを示している。

\section{3 減災情報共有データベースDaRuMa}

DaRuMa は、2.2 節で述べた MISP に準拠して動作す るプロトタイプ実装として開発されたデータベースであり、 減災情報共有プラットフォームでは各モジュールを連携させ
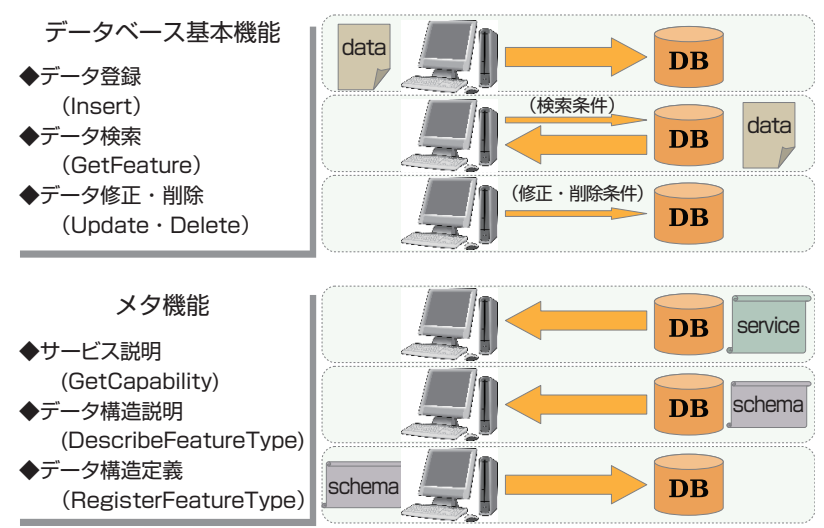

るハブとして働く。DaRuMa の設計・実装は以下の方針で 行われた。

・ダウンワードスケーラビリティとマルチプラットフォーム

動作環境として要求するスペックはできるだけ低く抑 え、また、幅広いOSやハードウエアをサポートする。大 災害時には情報通信インフラもダメージを受ける可能 性が大きく、高性能なサーバーや大規模なデータセン ターを確保できない場合もあり得る。そのため、できる だけさまざまな計算環境で動作可能であることを要件 の一つとした。

・既存ソフトウエアの利活用とオープンソース化

提案プラットフォームの目的は桨害時の情報共有の枠 組みの確立であり、新規のデータベース技術の研究開 発ではない。そのため、既存ソフトウエアを最大限活 用し、開発そのものにコストをかけないことを念頭に置 く。また、情報共有の枠組み確立と普及を円滑にするた め、成果物はオープンソースとして公開することを前提 として開発を進める。

実際に開発された DaRuMa は、図 5 に示すように、既 存の関係データベースである MySQL または PostGIS 注3) をバックエンドとして利用し、Javaでかかれたミドルウエア (MISP Processor) により SQL と MISP の仲介・変換 を行う構造になっている。このため、Java や MySQL・ PostGIS がサポートしている広範囲の OS・ハードウエアで DaRuMa を動作させることが可能になっており、Linux、 FreeBSD、Windows、MacOSの各バージョンでの動作 実績がある。さらには、機能的には制限されているが、 Rubyにより実装されたミドルウエアもあり、Linux Zaurus 等の隽帯端末でも動作させることが可能となっている等、 ダウンワードスケーラビリティを確保している。また、シス テムとしても軽量となっており、4.2 節で述べる実証実験で も、旧式のノート PC (Mobile Pentium III $933 \mathrm{MHz}$ 、メ

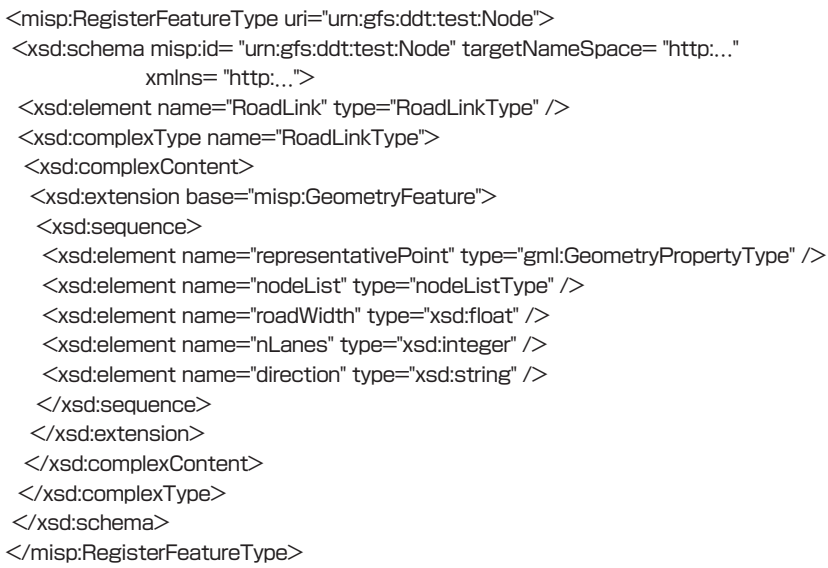

図 4 MISP のデー夕構造定義例 (RegisterFeatureType)

図 3 MISP の基本機能 
モリ 512 MB）を用いて 30 分間で 8,000 件を越える住民 通報を受けつつ他の情報システムやシミュレーションの連 携を取り持つことに成功している。この性能は中規模都市 の災害情報システム連携としては十分と考えられ、いざと いうときには用済みの PC を活用して情報システムを稼働 させることもできるようになっている。これを容易にするた めに、USB でブートすれば自動で DaRuMa が稼働する Linuxのライブイメージも作成している。

DaRuMa の開発と平行して、DaRuMa と各種システムを 接続するッール群の開発・整備も進めている。減災情報共 有プラットフォームでは、すべてのモジュールは DaRuMa と MISP により通信することになっている。しかし既存の 災害情報システムをすべて MISP 対応に変更することは現 実的ではない。それよりも、図 6 の右半分のように、既存 のシステムの機能をできるだけ活用して部分的にでも連携 を実現し、システム更新のタイミング等で徐々に連携を深 めていくことが有効であると考えられる。以下にあげるよう に、DaRuMaのツール群はそれらの部分的連携を支援す るものとして開発されてきている。

\section{•CSV 接続ツール}

CSV (Comma Separated Value) 形式で書き出され たデータをXMLに変換し、MISPを通じてDaRuMaに 登録するッール。また逆に、MISPにより取得したデー 夕をCSV形式ファイルに変換するツール。多くの災害情 報システムには、表計算ソフトの汎用データ形式であ るCSVファイルの入出力をサポートしていることが多 い。この接続ツールを整備することで、部分的な連携 自動化が可能となる場合がある。この連携自動化の ために、定期的に時間的差分デー夕を入出力したり、

DaRuMaからのデータ取得に条件を指定したりする機
能をもつ。

·GIS ビューワ連携ッール

DaRuMaに格納されている情報のうち地図上の位置に 結び付けられた情報（地物、Feature）を、KML等に 変換し、GoogleEarthやGoogleMap等のGISビューワ に表示するツール。地物が主体となる桨害情報では、モ ジュール間の連携をとるためにはデータベースに格納さ れている情報を随時地図上で確認できることが大切で ある。また連携支援だけでなく、GoogleEarth等の高性 能で無償・廉価なGISビューワは関係機関への情報提 供手段としても有効であり、それへの接続ッールの存在 は既存ソフトウエアの利活用の上でも重要である。

・ログ再生ツール

DaRuMaへのMISPの通信やデータベースの操作を夕 イムスタンプ付きで記録したログを活用し、共有情報 の変化を時間軸を含めて再現するッール。複数モジュー ルの連携を調整する場合、それらのモジュールを絶え ず利用可能にしておくことが難しい場合がある。特に 複数の組織・機関に跨がる連携を進める場合、連携調 整のために相手先のモジュールを利用できる機会は限 られる。ログ再生ツールは、記録しておいた相手先モ ジュールの動作を擬似的に再現できるため、連携調整 を簡便にすることが可能となる。また、このッールは擬 似的な合同訓練を実施する場合にも活用できる。

\section{3 データ仲介を核とした災害情報システム連携 \\ 3.1 システムのライフサイクルとデータの継続性}

災害情報を共有・活用する仕組み、特に情報システムを 設計する上で留意しなければならないのが、災害と情報技 術のライフサイクルの違いである。

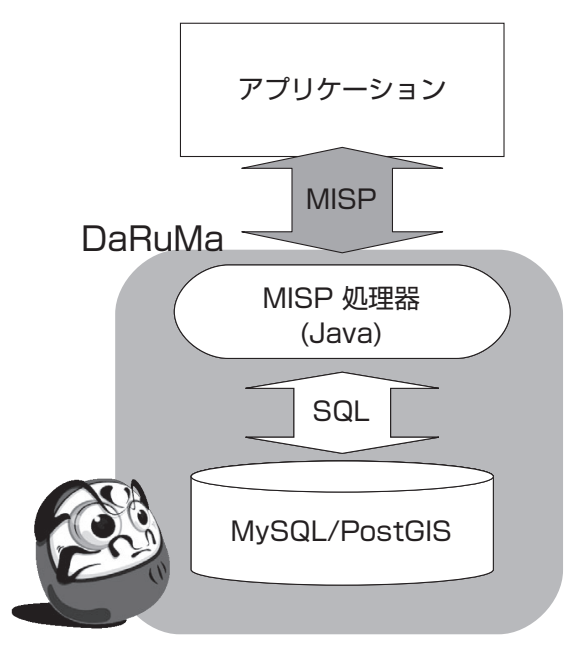

図 5 DaRuMa の構造
新規開発アプリケーション

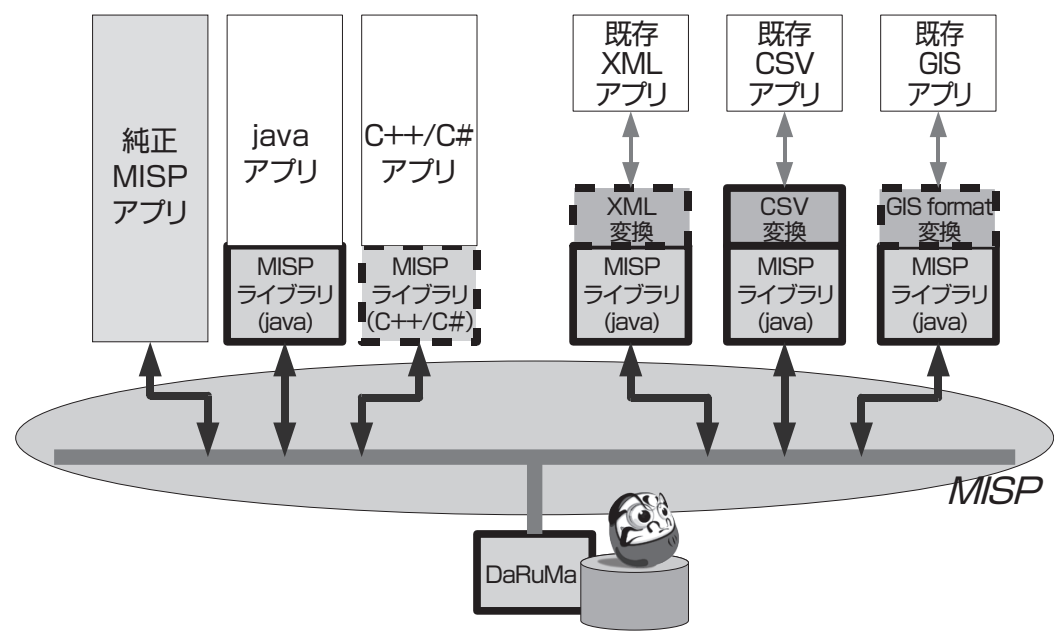

図 6 減災情報共有プロトコル MISP と DaRuMa によるシステム統合 
多くの災害は不定期、しかも長い時間間隔をおいて起こ るものである。例えば地震では、社会的な被害の出るよう な規模の地震は、ある特定の地域で見れば、数十年〜数 百年、場合によっては千年のスパンでしか起こらない。比 較的頻度の高い風水害にしても、毎年必ず襲ってくるもの

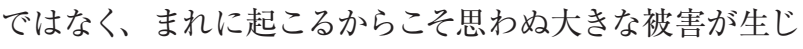
ることになる。裏を返せば、まれな時を除いた残りの期間 は、災害情報システムは、訓練等を除いてほとんど稼働し ないことになる。一方、情報技術の進歩は日進月歩である。 自治体がもつ災害情報システムは、だいたい 5 〜 10 年の 間隔で更新されることが多く、その更新の夕イミングで時々 の最新技術や機能が組み込まれていく。それと同時に、古 びた技術や機能は徐々に外されていく。このためほとんど のシステム・技術は、ほんの数回、場合によっては全く実 際の災害に使われずに役割を終えることになる。

このライフサイクルの時間スケールの差を乗り越えるの がデー夕の継続性である。システムの頻繁な更新に比べる と、デー夕は長期に渡って蓄積されるものであり、その寿 命は長い。特に再利用可能な形で記録されたデータの価值 はなかなか古びないことが多い。先にも述べているように、 自治体の情報システムは 5 ～ 10 年間隔で更新されるが、 その更新の際にデータがいかに引き継がれるかが重要とな る。このことから、災害情報共有のシステムを設計する上 では、十年・百年の長期にわたるデー夕の再利用性・蓄積 性を中心に考えることが有効である。

\section{2 データ中心による臨機応変なシステム連携}

データ中心の考え方は、臨機応変なシステム連携の視点 でも重要である。災害への対処は数多くの組織が関わる活 動であり、災害情報システムもそれらの組織を跨って運用さ れなければならない。このような複数組織が関わる情報シ ステムをモノリシックに設計・実装することは、現実問題と して難しい。よって、各組織がサブシステムとして個別に情 報システムを設計・構築し、それらを連携させることが現実 的な解となる。この場合、その連携を機能中心に設計する か、データ中心に設計するか、二つの考え方がありうる。

機能中心のシステム連携の一例が、WSDL (Web Services Description Language) や UDDI (Universal Description, Discovery and Integration）を活用した ウエブサービス連携である。ウエブサービス連携では、各 サーバーがさまざまな機能を実現・公開し、それらを組み 合わせて高次のサービスを実現する。この考え方は、多様 な要求に柔軟に応えることを容易に実現できるという点で 優れており、さまざまな対応が求められる贸害救助でも有 用な考え方ではある。しかし、各サーバーは「連携」を意 識した設計・実装を行う必要があり、各自治体において必
要な機能をそろえておく必要がある。

データ中心のシステム連携は黒板モデルで代表される。 この黒板モデルでは、各サブシステムは共通領域 (黒板) にデータを提供し、あるいはそこにあるデータを取得するこ とで、サブシステム同士の連携を実現する。この考え方で は、黒板にデータが提供されれば各サブシステムを機能さ せることができ、各サブシステム同士の「連携」を意識す る必要はない。一方、機能を密にあるいは柔軟に組み合わ せることは難しく、多機能・高機能の実現には向かない。

災害情報システムは日本全国の自治体で活用されること を考えると、システム連携の仕組みは機能中心よりもデー 夕中心とすべきである。南北に広がる我が国では、災害の 種類も多岐にわたり、雪害に悩む地域もあれば、水害を最 重要視しなければならない地域もある。よってそこで必要 とされる機能もさまざまであり、組み合わせも複雑となる。 また、自治体の防災体制や関係組織は画一的ではなく、 サブシステムの構成方法も異なってくる。このため、必要と される機能やデータをどのサブシステムに担わせ、不足して いるものをどう補うかが重要となるが、不足機能の補填は 即席では困難である一方、不足デー夕については、精度や 動的性·正確性の劣化を許容すれば、補うことは難しくない。

さらに、東日本大震災を被災した自治体でのヒアリング ${ }^{[5]}$ によると、さまざまな想定外の事象により、多くの自治体 では事前の防災計画をいろいろと手直しせざるを得なかっ たことが明らかになっている。この震災を契機に各自治体 での防贸計画はさまざまな形で見直されると思われるが、 それでも想定外のことは起きるものとして、対応の柔軟性 を確保しておくべきである。それに伴い、情報システムも事 後に機能の組み替えを行うものとして設計されなければな らないといえる。そして、この事後の組み替えを迅速に行 う鍵として、デー夕仲介による単純な連携は効果的である。 これについては、次章の実証システムで事例を示す。

このデータ中心のシステム連携は、オープンソースでの プログラム開発にも通じる考え方である。E. Raymond は 「伽藍とバザール」(http://cruel.org/freeware/cathedral. html）の中で、有名なハッカーの言葉として以下のような 記述をしている。

“賢いデー夕構造と間抜けなコードのほうが、その逆より ずっとまし。（フレデリック・P・ブルックス著「人月の神 話」第十一章)

“コードだけ見せてくれてデータ構造は見せてもらえな かったら、私はわけがわからぬままだろう。デー夕構造さ え見せてもらえれば、コードのほうはたぶんいらない。見 るまでもなく明らかだから。”

比較的緩い方針の下で多数の人間により開発が進められ 
るオープンソースのシステム開発では、他の人が作成したモ ジュールをどう再利用するかが重要となる。上記の言葉は、 モジュールの機能ではなくモジュールが扱うデータ構造の方 が、その再利用のための知識の受け渡しがスムーズである ことを示していると言える。災害情報システムも同じく、多 数の人間・組織が部分的なモジュールの設計・開発に携わ る。また、その開発スパンも長期にわたるものであり、そ の設計思想やアーキテクチャの知識の伝承は重要となる。 その意味においても、データを中心としたモジュール連携 の考え方は、災害情報システムの開発手法として的を射て いると言える。

\section{4 実証システム}

この論文で提案している減災情報共有プラットフォーム は、文部科学省の大都市大震災軽減化特別プロジェクト、 科学技術振興調整費、安全安心科学技術プロジェクト、 首都直下地震防災・減災特別プロジェクトおよび経済産業 省の戦略的先端ロボット要素技術開発プロジェクト等を通 じて開発を進めてきた。そして、これらのプロジェクトを通 じて数多くの連携システムを構築し、実証実験を行ってき た。この章ではこのうち、見附市と豊橋市の実証実験の概 要について述べる。

\section{1 見附市実証実験}

災害時には、現場から報告された情報および各部署間で の情報の共有が重要である。提案アーキテクチャに基づく 各種災害情報システムを多数連携させる試みとして、2006 年 10 月 27 日に新潟県見附市市役所にて、水害を対象とし
て防災、減災に関わる多数の機関、多数の各種情報システ ムの DaRuMaを介した情報システム統合を行う実証実験を 行った (図 7)。この実験では、市役所の複数の関係部署 および消防・警察と、電力・ガス等のライフラインの情報を DaRuMa を介して統合し、相互に情報を共有することを試 みた。同時に、災害ボランティア等からの携帯端末を使っ た通報や水位観測センサーからの自動通報等も統合し、災 害対応にあたる職員が情報の整理に忙殺されることなく、 災害対応活動に専念できる統合システムを構築した ${ }^{[13]}$

この実験の特徵は、図 7 に示した 10 以上に上る多数 の情報システムの連携を延べ 3 日で実現した点である。一 般にシステムの連携は、その機能合わせやプロトコルの擦 り合わせ等で時間を要することが多く、特に別々に設計・ 実装されたシステムを連携させる場合、かなりの工数を要 することになる。一方、提案のプラットフォームでは、連携 はすべて DaRuMa 上におかれたデータを介してのみに限 定し、プロトコルも MISP という単純なデータベースプロト コルとしている。これにより各システムの改変は MISP の対応という形で最小限で済み、また、個別システムと DaRuMa の接続テストが容易であったため、短時間での 接続が可能となったと考えられる。

この実験は市役所の防災訓練の一環として行われ、実 際の市の防災担当職員により、現実的な災害シナリオにのっ とって進められた。こういったシステムの評価は難しいが、 システム連携により情報が一元化できたことで、災害対応 を確実にできるという評価を、訓練を体験した職員より得

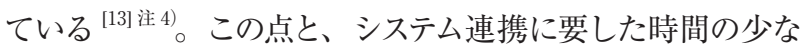

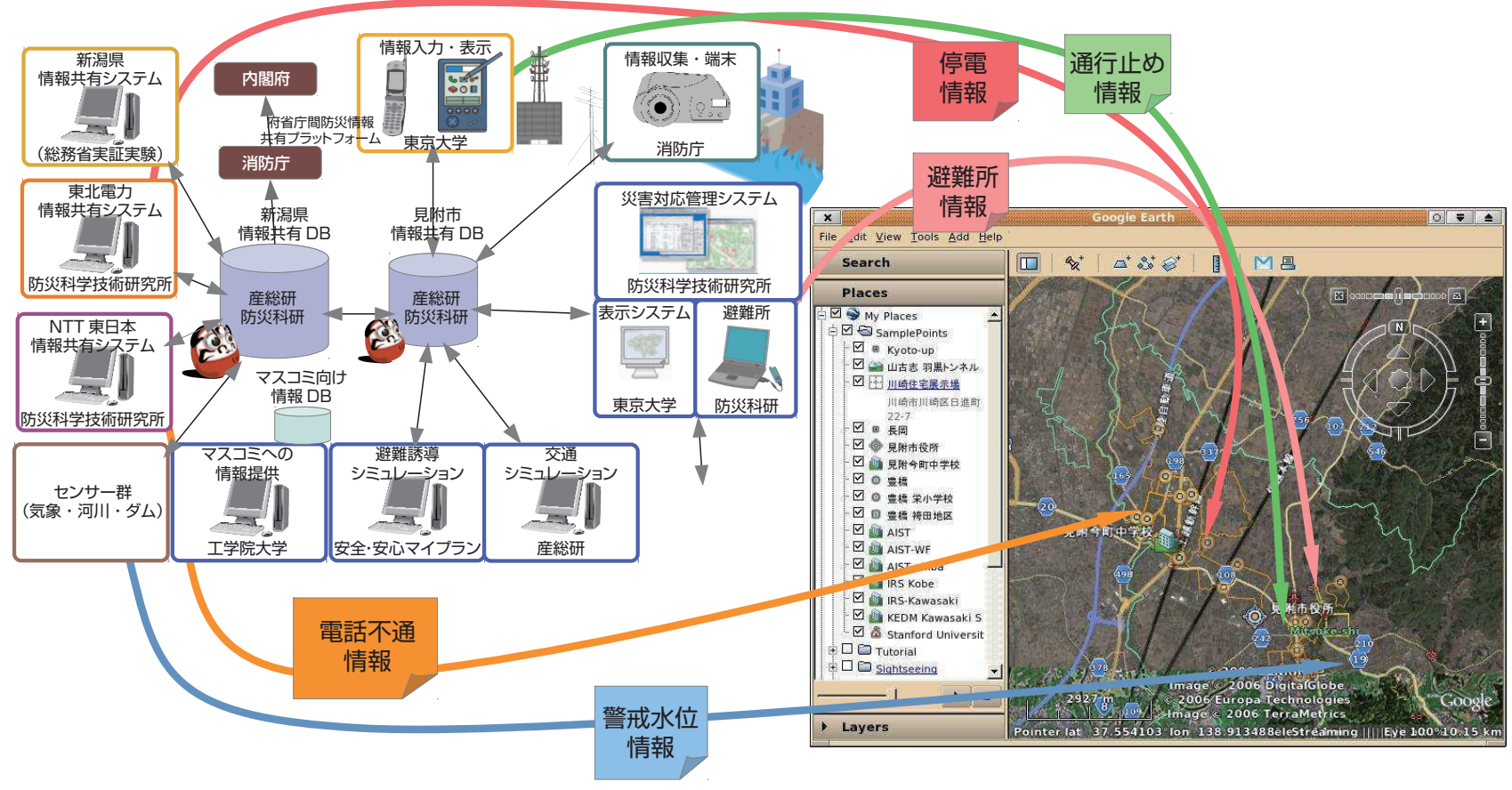

図 7 見附市実証実験全体図 
さにより、プラットホームの設計思想の有効性が示されて いると考えることができるだろう。

\section{2 豊橋市実証実験}

2006 年 11 月 12 日に愛知県豊橋市にて、地震を対象と して多数の各種情報システムを DaRuMa を介して統合した （図 8）。この実験では、避難所に集まる市民からの膨大 な情報をDaRuMa を使って整理・統合し、それらの情報 を元に、火災延焼や交通渋滞予測、避難経路探索等を行 い、災害対応行動を円滑に進めるのに有用な情報提供を 行うことを試みた ${ }^{[14][15]}$ 。つまり、避難所に逃げてくる住民 が避難途中に見た地元の被害状況を避難所で報告しそれ をシミュレーション等に反映することで、被害想定や桨害対 策の精度をあげることを狙っている。同時に、そういう住 民の情報収集活動が災害対策に役に立つことを分かりやす い形で示し、住民の防倓意識、当事者意識を喚起するこ とも目的としている。

この実験の提案プラットフォームとしての主眼はシミュ レーション連携である(図 9)。複数シミュレーションの連 携ではシミュレーション間の接続で入念な境界条件の依存 関係調整等が必要となる。この実験ではこの依存関係を 一方通行で単純化するという割り切りを行い、簡便に連携 を実現した。この割り切りはシミュレーション連携の厳密

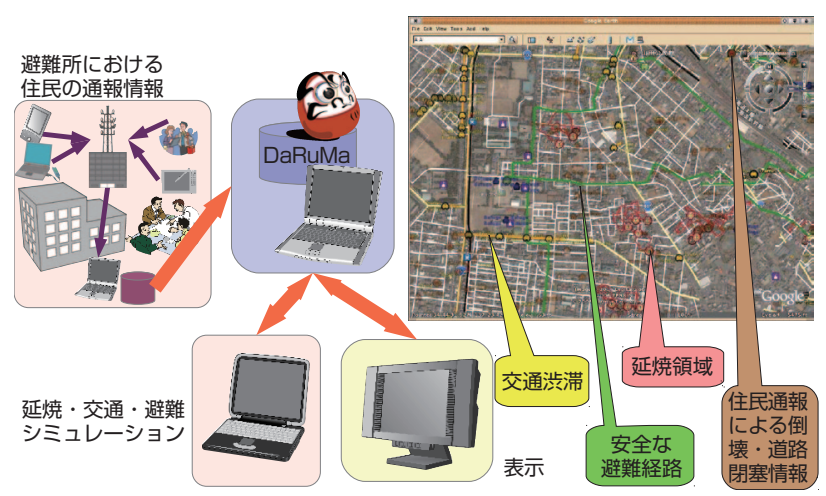

図 8 豊橋市実証実験のシステム構成

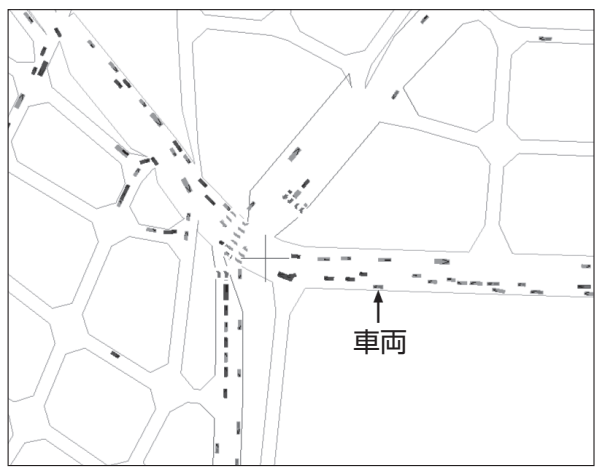

（a）道路被害情報なし
さという点では劣るが、災害救助という文脈ではそれでも 十分に活用できる場面が多くあり、有効な手段である。ま た、データベースによる仲介ということで、複数のシミュレー ションを実行する計算機環境を無理に合わせる必要がない 点も、臨機応変にさまざまな組み合わせのシミュレーショ ン連携を実現する上で大切である。なお、各シミュレーショ ンシステムの動作は、以下のとおりである。

・延焼シミュレーションシステム

現地から報告された出火情報等を初期設定とし、延焼 予測を行う。

・避難シミュレーションシステム

道路被害情報、延焼シミュレーターによる火災による 危険道路予測、避難の出発地・目的地等の設定を情報 共有データベースから取得し、避難に適した経路を解 析する。

・交通シミュレーションシステム

道路被害情報、避難経路を取得し、それらの道路の通 行に制限がある設定でシミュレーションを行い、渋滞・ 混雑が発生すると予測される道路を予測する。

図 10 に道路被害情報の有無による交通シミュレーショ ン結果の変化の例を示す。この例では、右上から中心にか かる幹線道路での閉塞情報がシミュレーションに反映され た場合とそうでない場合の交通渋滞の予想の違いを示して

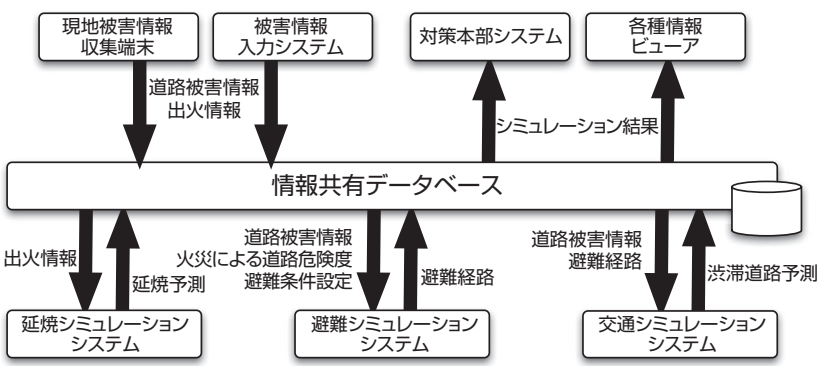

図 9 豊橋市実証実験のシステム構成

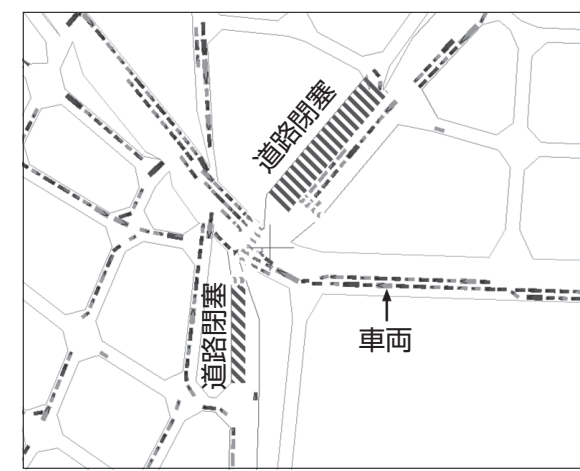

（b）道路被害情報あり

図 10 道路被害情報の有無による交通シミュレーション結果の変化（豊橋市高師口付近） 
いる。このように、各種シミュレーションモジュールは、条 件となる情報を情報共有データベースから取捨選択するだ けでなく、シミュレーション結果を情報共有データベースに 出力する。これによって、その結果を対策本部のシステム 等で被害情報とともに確認したり、別のシミュレーションモ ジュールで利用することを用意に可能としている。このよう に通報や各種シミュレーションの連携を単なるデー夕連携と して扱うことで、確度の高い情報のみの分析や一般市民の 通報やシミュレーションの予測を含む確度の低い情報を取 り込んだ予測等、さまざまなレベルのシミュレーションを容 易に実現できることを、この実験のシステムは示している。

見附市実証実験と同様に実証実験後に市役所職員へ評 価のための聞き取り調查を行った。その結果として、「被害 想定、応急対応需要量、応急対応項目は災害対策本部ま たは災害対策本部員会議で参加者全員が共通認識をもっ て初動に取り組む際に必要なものであると思われる」、「実 験で提案された仕組みは行政機関等が行う情報収集と合 わせ有効な手段となりうる」との評価を得た。

\section{3 通れた道路マップ}

大災害時における救助救援活動を円滑にするためには、 救助隊や物資輸送隊が移動するための道路の情報、特に 通行可能な道路の情報が必要となる。しかし、通常、自 治体や警察が提供する道路情報は通行不能情報あるいは 通行制限情報であることが多く、しかも情報として網羅で きているわけではないため、救助隊、特に遠隔地からの救 助隊にとって目的地までの経路を確実に見つけることは困 難であることが多い。

この問題を解決する方法として考え出されたのが、道路 の通行実績情報である。これは、一般の自動車の走行デー
夕をもとに、発災後のある日、あるいはある時間帯に実際 に利用された道路を抜き出し、地図データとして統合する ものである。何台かの自動車が実際に走っていることか ら、少なくともその道路はある程度利用可能であることが 期待できる。特に近年は通信機能を有するカーナビを搭載 する自動車が増え、特定地域の道路をかなり網羅した通行 実績を示せるようになってきている。また、走行実績の台 数により道路を分類することも可能であり、基幹道路として の使用可能性を推定することもできる。

産総研は、本田技研工業(侏) (以下、HONDA) の協力の もと、東京大学の秦康則氏 (現山梨大学) らと共同して、 2007 年 7 月の中越沖地震の際にこの通行実績情報を「通 れた道路マップ」（図 11）としてとりまとめ、Webにて情 報提供を行った ${ }^{[16]}$ 。この「通れた道路マップ」では、次 のような手順で各道路の通行実績情報を処理した。まず HONDA の通信カーナビゲーションシステムのセンターに は、同サービスを受けている車輛の実走行経路データが集 積されている。このデー夕の内、被災地域にかかっている ものを 1 日分取りまとめ、個人情報の匿名化 ${ }^{\text {主 } 5)}$ ・ハズレ值 や誤差の除去・道路データとのマッチングを行った後、各 道路の平均速度を求め、通行状況を 3 段階に分類する。 その結果を GoogleEarth 上で地図情報と重ね合わせて表 示し、画像デー夕としてWeb 上で公開した。この情報は 1 日ごとに更新され、日々、前日の通行実績を確認できるよ うにしてきた。

この「通れた道路マップ」作成過程は、減災情報共 有プラットフォーム上で実現され、各工程の途中経過は DaRuMa 上に保存していた。この処理は発災後に試行錯 誤しながら実現していったが、DaRuMa 上のデータ仲介

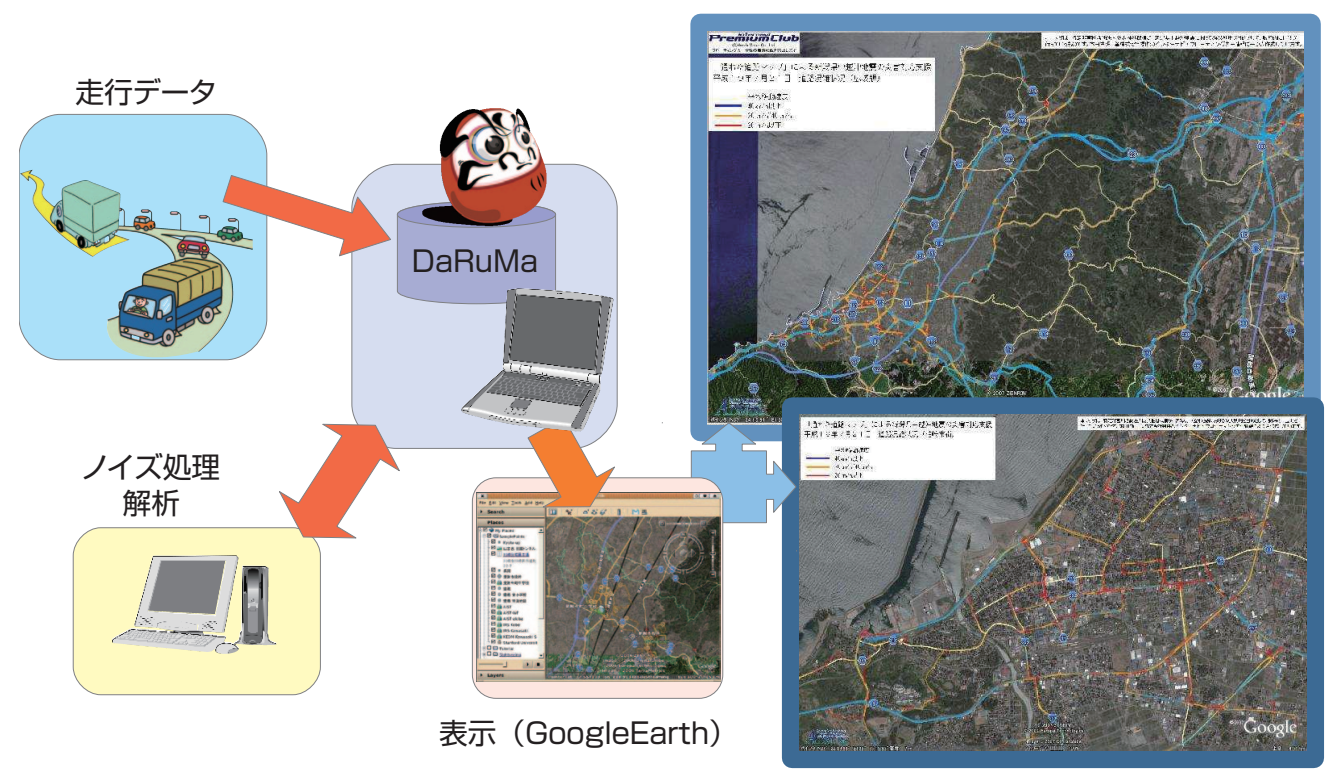

図11 中越沖地震で情報提供した通れた道路マップ 
の形をとっていたおかげで試行錯誤が手早く簡潔に行え、 発災後 3 日目には情報提供に漕ぎ着けることができた。

なお、後で述べるように、この通行実績情報は処理方法 として確立できたため、東日本大震棪では HONDA から 直接一般に提供されることになり、その後、TOYOTA、 ITS Japan からの情報提供として広がっていった。さらに は、 2011 年 9 月の台風による紀伊半島の水害においても、 ITS Japan から同様の情報提供が行われ、災害情報の一 つとして定着してきている。

\section{5 東日本大震災をふまえて}

2011 年 3 月 11 日の東日本大震災では、多くの防災関係 者が自らの無力さを思い知らされることとなった。この論 文執筆時点での死者・行方不明者数は 19,503 人に上り、 福島第一原子力発電所の事故も含めれば、経済的被害は 今だ増え続けている。

ただその中においても、少しでも被害を少なくする減桨 への取り組みの試行錯誤がさまざまな形で行われた。それ を可能とした要因はさまざま考えられるが、この論文で提 案したプラットフォームの設計方針、すなわち、オープンシ ステム、標準、ダウンワードスケーラブルの考え方は有効 に働いたと考えることができる。

この震災では、インターネットを介した情報ボランテイア による被災地支援が多く見られた。例えば Google 等が中 心となった Person Finder では、手書きの避難者名簿をデ ジカメで撮り、被災地外のボランティアがテキストデータと して打ち込み、データベースを作り上げた。この単純であ るが効果的な方法は、クラウドコンピューティングや高速イ

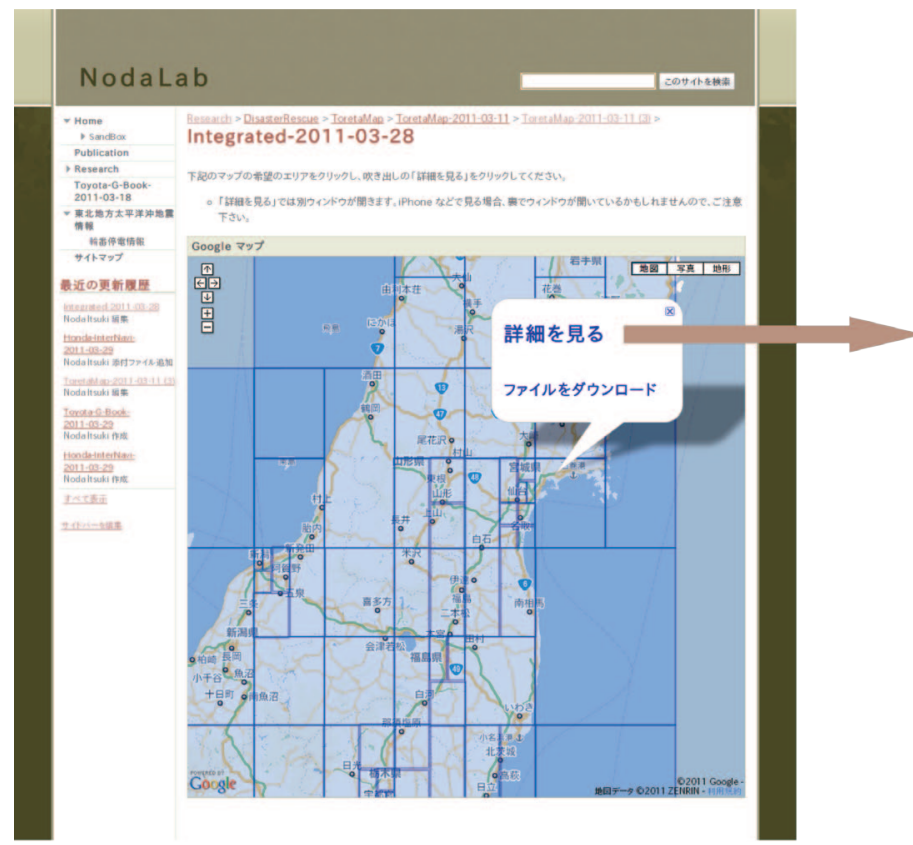

図 12 東日本大震災で情報提供した通れたマップ
ンターネット等の先端技術に支えられてはいるものの、機能 としては単純なもの（デジカメによる撮影、人間による文字 認識、データベースの検索）を、画像データやテキストデー 夕で仲介したと見なせる。人間による処理のように時間的 に遅れがあっても問題なく連携できているのも、機能では なくデータで仲介している効果であると言える。

4.3 節で述べたように、「通れた道路マップ」（道路通行 実績情報）も、HONDA や TOYOTA、ITS Japan 等か ら大規模に展開されたが、今回は KML という国際標準の フォーマットを用いて詳細データが公開された注6)。このた め、このデータを用いたさまざまな情報統合の試みがなさ れた。例えば筆者らはこの通行実績情報を軽量化しつつ、 ガソリンスタンド・道路通行止め情報等を統合した地図を 作成して情報提供してきた (図 12) ${ }^{[17]}$ 。また、PC 等でしか 参照できない通行実績情報を携带電話等でも参照できる 画像ファイルに直す取り組みをしていたボランティアも見ら れた。このようなさまざまな試みが同時並行で取り組める ことは、防災における多種多様な要望に応える一つの解と 考えられる。そしてそれを可能とする土台の一つが、汎用 フォーマットによるデータを仲介することで処理を組み上げ ていく点にあることは、もっと注目されるべきであろう。こ のような草の根的システム開発や、改変・連携を中心とした アドホックなシステム構成は、人命を預かるという重い使命 を担う災害対策では敬遠されがちである。しかし想定外を 含めた事態への臨機応変な対応が求められることを考える と、このような緩いがしなやかな手法の併用も想定してお かなければならず、その準備として、オープンシステム・汎 用フォーマット/プロトコル標準・ダウンワードスケーラビリ

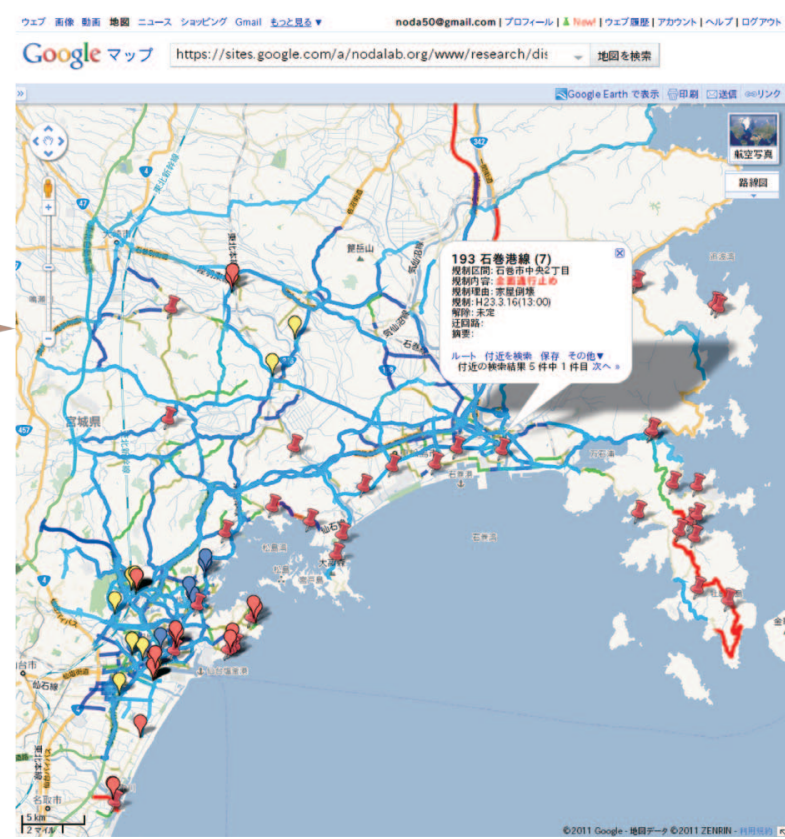


ティという考え方に基づくシステム構成の考え方を広げてい かなければならない。

\section{6 おわりに}

この論文ではデータ仲介を核とするモジュール連携という 考え方を元にした災害情報システムの設計方針と、それの 実装である減災情報共有プラットフォームについて述べた。

デー夕仲介の考え方は粗で簡潔なモジュール連携を目指 すものであり、高機能の高度な連携よりも、単純な機能の 臨機応変な連携を実現する。

3 章で議論したように、さまざまである災害は多かれ少 なかれ想定外の事象を含むものであり、各自治体に柔軟な 対応が求められる。東日本大震災での多くの事例では、そ のような臨機応変の対応の必要性と、それを支えるための データ仲介によるアドホックなシステム構築の有効性を示し ている。

もちろん、単なるデー夕連携ですべての防災業務が賄え るわけではなく、また、プライバシーに関する情報を扱うた めのセキュリティー技術や、大量のデータを確実・高速に 処理する枠組み等が、技術の進歩とともに必要となり可能 となっていく。それらの変化に対応しながら、この論文で 提案した考え方やプラットフォームを今後も発展させていか なければならない。

\section{謝辞}

この研究は文部科学省の大都市大震災軽減化特別プロ ジェクト、科学技術振興調整費、安全安心科学技術プロ ジェクト、首都直下地震防災・減災特別プロジェクトおよび 経済産業省の戦略的先端ロボット要素技術開発プロジェク トの支援を受けた。またこれらのプロジェクトに関与され た多くの方々の協力のもと、システムの開発が進められた。 ここに感謝したい。

注1）より小規模・貧弱な情報処理機器で運用しても、その機器 の能力に応じて機能を維持できるようにシステムを設計する考え 方。規模が拡大しても機能を維持する「(アッパーワード) スケー ラビリティ」に対する概念である。

注2) マルチメディアデータについては、MIME形式等いくつか 標準形式はあるが、データサイズの問題やストリーミング型等 XMLでは扱いづらいタイプも存在する。これらについては、今 後、XMLにこだわらず、長期に渡って機能することを重視した形 式を採用していく必要がある。

注3) バックエンドデータベースとの接続部分は独立性が高く実装 されており、他のデータベースへの切り替えも容易になっている。

注4) 見附市は2004年7月の7.13水害において甚大な被害を経験 しており、多くの職員はその際に情報の錯綜による対応の困難さ を経験している。このため、この実験においてもその時の経験を もとに実運用を想定して評価を行ってもらっている。

注5) 単一の通行実績しかない場合は個人が特定できてしまう 可能性があるため、複数の通行実績があるところのデー夕のみ
を抽出した。

注6) 中越沖地震の際には、個人情報保護の観点から詳細情報 の公開ができず、道路地図の画像情報での提供にとどまった。 東日本大震災の際には個人情報保護にめどがついたため、詳細 な情報提供が可能となった。

\section{参考文献}

[1] 内閣府(編): 平成22年版防災白書, 内閣府 (2010)

[2] Munich Re Group: Statistics and natural hazard risk for 50 selected megacities, Jan (2005).

http://www.munichre.com/app_pages/www/@res/pdf/ media_relations/press_releases/legacy/pm_2005_01_11_01_ en.pdf

[3] 座間信作, 細川直史, 関沢愛: 地震被害情報の効率的収集 方法, 第10 回日本地震工学シンポジウム, 3479-3484 (1998).

[4] 山田博幸, 古戸孝, 浦山利博, 角本繁: 自治体の地震防災に 貢献する防災情報システムの構築に関する研究, 地域安全 学会論文集, 6, 67-74 (2004).

[5] 野田五十樹, 近藤伸也, 沼田宗純, 秦康範: 災害対応の現状 と求められる情報システム一東日本大震災での災害対応ヒ アリングを通じて一, 人工知能学会「社会における $A I J$ 研究 会第13 回研究会予稿集, 人工知能学会 (2011).

[6] I. Noda et al.: IT framework for disaster mitigation information sharing, Journal of Disaster Research, 3 (6), 467-478 (2008)

[7] 下羅弘樹, 松井宏樹, 野田五十樹: 分散システムアーキテク チャによる防災システム連携, 日本地震工学会論文集, 9 (2), 61-72 (2009).

[8] 防災科学技術研究所, 産業技術総合研究所, 減災情報共 有プロトコル, (2005).

http://www.kedm.bosai.go.jp/project/info-share/infosharp/ index.html

[9] Open GIS Consotium, Inc. Web Feature Service Implementation Specification (OGC02-058), ver. 1.0.0 edition, May (2002). https://portal.opengeospatial.org/files/?artifact id=7176

[10] Open GIS Consotium, Inc. OpenGIS Geography Markup Language (GML) Implementation Specification (OGC-02$023 r 4$ ), ver. 3.00 edition, Jan. (2003). http://www.opengis.org/docs/02-023r4.pdf

[11] W3C. Xml schema part 2: Datatypes second edition, chapter 3. built-in datatypes. http://www.w3.org/TR/xmlschema-2/\#built-in-datatypes

[12] World Wide Web consortium (W3C). Soap version 1.2, (2001) http://www.w3.org/TR/2001/WD-soap12-20010709/

[13] 鈴木猛康, 秦康範, 天見正和: 災害時情報共有に関する 実証実験の実施と評価, 日本災害情報学会誌，6，107-118 (2008).

[14] 村上正浩, 柴山明寛, 久田嘉章, 市居嗣之, 座間信作, 遠藤 真, 大貝彰, 関澤愛, 末松孝司, 野田五十樹: 住民・自治体協 働による防災活動を支援する情報収集・共有システムの開 発, 日本地震工学会論文集, 9 (2), 200-220 (2009).

[15] 柴山明寛, 久田嘉章, 村上正浩, 座間信作, 遠藤真, 滝澤修, 野田五十樹, 関沢愛, 末松孝司, 大貝彰: 被害情報収集支援 システムを用いた災害情報共有に関する研究，日本地震工 学会論文集, 9 (2), 113-129 (2009).

[16] 鈴木猛康, 秦康範, 下羅弘樹: 災害時の道路情報提供の試 み新潟県中越沖地震における取組みと今後の展開一, 日本災 害情報学会第9回学会大会予稿集, 11月2007, 通れたマップ.

[17] 東日本大震災通れた道路マップ. https://sites.google.com/a/nodalab.org/www/research/ disasterrescue/toretamap/toretamap-2011-03-11/ toretamap-2011-03-11-11 


\section{執筆者略歴}

野田 五十樹 (のだいつき)

1992 年京都大学大学院工学研究科修了、通 商産業省工業技術院電子技術総合研究所に入 所後、改組を経て現在、独立行政法人産業技 術総合研究所サービス工学研究センターサービ 又設計支援技術研究チーム長。筑波大学大学 院および東京工業大学大学院の連携講座教授 を兼務。博士 (工学)。マルチエージェント社会 シミュレーション、災害情報システム、機械学習

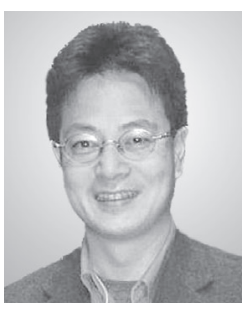
の研究に従事。人工知能学会、情報処理学会会員。人工知能学会、 RoboCup Federationa、ロボカップ日本委員会、防災推進機構 理事。

\section{査読者との議論}

\section{議論 1 シンセシオロジー論文としての主張点の整理}

コメント (中島 秀之: 公立はこだて未来大学)

データ仲介によるシステム連携によって実現された災害情報システ ムについての論文であり、さまざまな、あるいは将来の情報システム を連携させようという、事前にすべてを規定できない開いた系を対象 としたシステムを構成 (シンセシス) することを目的としたもので、シ ンセシオロジーの論文として、とてもふさわしい論文です。

シンセシオロジーの編集方針として、こういった開いた系に対する システム構築における基本方針が明確に述べられていることを期待し ていますが、実際に本文中にそういった基本方針が書かれています。 ただ、個々の記述については良く理解できるのですが、全体としての 考え方が読者に分かるような工夫があるとよいと思います。特に、「構 成的手法」をもう少し強調していただき、サービス工学としての手法 を中心に据えた記述が望まれます。

第 1 章において、「オープンシステム、標準、ダウンワードスケーラ ビリテイ」の 3 点が設計の基本方針として掲げられています。一方、 2.1 節拈よび 3 章においてデータ中心 (あるいはデー夕仲介連携) の 考え方、2.3 節では、設計・実装方針として、1）ダウンワードスケー ラビリティとマルチプラットフォーム、2) 既存ソフトウエアの利活用と オープンソース化の 2 点が掲げられています。これらの対応関係が必 ずしも明確ではないようです。図あるいは表で全体的な考え方を整理 して、それに則って記述をしたらさらに分かり易くなると思います。

一案ですが、災害情報システムが備えるべき特徵を揭げて、それ からトップダウン的に必要要件を位置付け、それに対応して実装した 機能を位置付けることができると思います。以下のような理解で良い でしょうか?

\section{災害情報の特性}

•さまざまな組織（あるいは個人も?）がいろいろな規模の災害情報シ ステムを運用

•災害と情報技術の時間スケールの違い

•災害対策は頻繁に修正、場合によっては大幅修正が必要

これらの目的を満たす連携プラットフォームとして、データ仲介による システム連携が好適である。

それを実現するための要件を整理すると

・新規の連携接続を簡単にするため

- 沉用性の確保: 沉用的な入力形式、沉用的な出力、共通的構造等

・新規連携のための作業を簡便に

・計算機能力を問わないで済むため

がある。

これに対して、実装したときのポイントとなった機能としては、

・データを介したモジュール連携: 各種災害情報システムを連携させ るため
・データ構造定義機能: 新規モジュール追加時にリアルタイムに新規 データ型のテスト・修正ができる

・MISPの基本機能に標準を採用 : 既存システム、将来システムとの親 和性を高める。簡潔であり計算能力のないセンサーシステムでも扱える ·XMLの採用: 汎用性、柔軟性、拡張性

・要求動作環境を低く: 大型サーバーが機能しないことも想定して、 小型端末でも動作可能

・オープンソース化 : 情報共有枠組確立と普及の円滑化

•MISPのみに限定せずに部分的にでも連携できるためのツール群

$\star \mathrm{CSV}$ 接続ツール: 表計算ソフトウエアの汎用データ形式がシステム で広くサポートされている

ŁGISビュワー連携ツール：GoogleEarth等のGISビュワーに表示する ツール

Łログ再生ツール : 各モジュールの共有情報の変化を時間軸を含めて 再現するツール。連携調整を簡便に。

等がある。

これらの機能と上記要件とをマトリックス的に関係付けた表あるい は図等を追記していただくと、研究目標に対するシンセシスの考え方 （研究のシナリオ）が明確になり、シンセシオロジー論文として有益 な情報を読者に提供できると思います。

回答 (野田 五十樹)

有益なご指摘、ありがとうございます。ご指摘のとおり、論文全体 の流れとキーワードの関係が分かりにくくなっておりました。それを補 うために、第 1 節を大幅に加筆しました。また、キーワードの関係を 示す図も挿入いたしました。

\section{議論2 タイトル}

コメント2 (赤松 幹之: 産業技術総合研究所ヒューマンライフテクノロ ジー研究部門)

上記の主張点が分かるようなタイトルとサブタイトルを付けてくださ い。例えば「災害情報システム連携のためのプラットフォームの構成 ーデー夕仲介による長期にわたって変化するさまざまな情報システム の連携一」。主張点と合わせてご検討ください。

また、第 3 章の節タイトルについても、論文としての主張点が明確 になるようにご検討ください。

回答 (野田 五十樹)

タイトルについては、提案する技術である「プラットフォーム」を入 れることとしました。また、 3 章の節タイトルについても、第 1 節で取 り上げたキーワードを用いて、対応関係が分かるようにしました。並 行して、図1のキーワード関連図でも、節番号を付与しました。

\section{議論3 DaRuMa}

質問 (赤松 幹之)

図 7 を見ると DaRuMa が新潟県と見附市向けの二つがつくられた ようですが、二つないとうまく運用できなかったのでしょうか? 二つ の DaRuMa を導入した理由があれば記載してください。

回答 (野田 五十樹)

見附市の実験当時は、DaRuMa にアクセス制御機能がなかったた め、DaRuMa へアクセスできるシステムには全情報が参照できてしま うようになっていました。このため、市役所庁内で閉じておくべき情 報は DaRuMa に載せられず、庁内での情報共有が進まないという問 題が生じました。これを避けるため、内部用の DaRuMa と外部用の DaRuMa に分け、その間にフィルター機能のあるミラーリングッール を用意し、公開してもよい情報のみ外部用 DaRuMa に反映される仕 組みを用意しました。その後、DaRuMa（および MISP）にはアクセ ス制御機能を設けたため、現状ではこのような仕組みは必要なくなり ましたが、論文では実験当時のシステムの構成として、当時のままの 
ものを載せてあります。なお、アクセス制御についてはこの論文では 主題でないため、説明を省いてあります。

\section{議論4 マップ}

質問 (赤松 幹之)

この論文では、実証システムとして、見附市の実証実験、豊橋市 の実証実験、そして HONDA の通れた道路マップが示されています。 この研究では、実現場で実証することは極めて重要なことだと思いま すが、実証実験の場として提供してもらえた理由はどういったことが 背景にあるのでしょうか? 現場の人達が参画するモチベーションがど のような点にあったのか、分かる範囲で結構ですので紹介していた だけませんでしょうか (これらは、いずれも文科省、科振費等のプロ ジェクトメンバーだったのでしょうか。プロジェクトメンバーだったので したら、それぞれの組織がこのプロジェクトに参画することになった モチベーションが何だったのでしょうか。モチベーションのある組織 とモチベーションのない組織の違いはどこにあるのか等も、構成学と しては明確化していきたいと思いますので)。同様に、東日本大震災 でのITS Japanによる通れたマップは、だれが最初に働きかけて実 現したのでしょうか。

回答 (野田 五十樹)

現場となる自治体等との関係は、プロジェクト単発ではなく、事前
や事後に継続して維持することが最も大事であると言えます。この論 文で紹介した各実証実験を行った各自治体は、プロジェクトに参画し ていた研究者の個別のつながりで協力していただきました。このつな がりの多くは、自治体の首長や防災担当者が熱心であった等の偶然 がきっかけになっています。ただ、この偶然のつながりを各研究者が 大事に継続し、現地や現場に足を運しで共通の問題意識を培ってい くことで、新しい技術への理解が生まれ、実証実験に結び付いてい きました。各プロジェクトは数年の期間しかありませんが、自治体と のつながりはそれ以前から、あるいはプロジェクト終了後も続いてい るものが多くあります。私自身はここで紹介したプロジェクトで他の共 同研究者のつながりの恩恵を受けたに過ぎませんが、プロジェクト終 了後はできるだけ多くつながりを維持できるよう努力しています。

ITS Japan のケースについては、きっかけは、中越地震の際の山 梨大学の秦先生の着想を温めていたところ、中越沖地震でたまたま HONDA の協力が得られ、即席に造ったシステムで小規模に情報発信 できたことが発端になっています。この成功があったおかげで、東日 本大震災では HONDA や Google が動き出すきっかけができ、最終 的には ITS Japanのもとで、オールジャパンで情報発信する体制とな りました。この例でも、中越・中越沖地震の頃 (さらには、それ以前 よりさまざまなツールを造り始めた時期）から、NPO の研究会等の活 動を通じて関係を維持していた継続性が大事であったと考えています。 